\title{
ЕВАЛУАЦИЈА НА ВЛИЈАНИЕТО НА АЛКОХОЛИЗМОТ КАКО СОЦИОМЕДИЦИНСКИ ФАКТОР ВРЗ ПОЈАВАТА НА МОЗОЧНИТЕ КРВАВЕЊА
}

\author{
Иван Панговски ${ }^{1}$

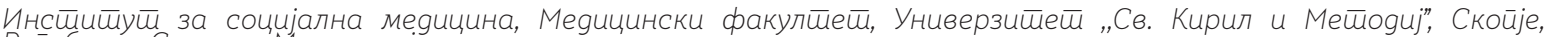
Рейублика Северна макеgонијаа

Цитирање: Панговски И. Евалуација на влијание то на алкохолизмот како социомедицински фактор врз појавата на мозочните крвавења. Арх Ј Здравје 2019;11(1):31-36

Клучни зборови: алкохолизам, мозочни крвавења, хипертензија, атеросклероза, ризик-фактори, јавноздравствен аспект

*Кореспонденција: Иван Панговски, Институт за социјална медицина, Медицински факултет, Универзитет „Св. Кирил и Методиј”, Скопје, Република Северна Македонија. E-mail: ivan.pangovski@ gmail.com

Примено: 26-ное-2018; Ревидирано: 23-јан-2019; Прифатено: 28-фев-2019; Објавено: 15-мар-2019

Печатарски права:²019 2019 Иван Панговски. Оваа статија е со отворен пристап дистрибуирана Оваа статија е со отворен пристап дистрибуирана овозможува неограничена употреба, дистрибуција ивозможува неограничена употреба, дистрибуција и репродукција на било кој медиум, доколку се тираат оригиналниот(ите) автор(и) и изворот.

Конкурентски интереси: Авторот изјавува дека нема конкурентски интереси.

\section{Извадок}

Цел на трудот: Да се утврди влијанието на консумирањето алкохол во појавата и лекувањето на хипертензивните мозочни крвавења и штетните последици врз морбидитетот и морталитетот на пациентите. Материјал и методи: Беше изведена ретроспективна студија кај 61 пациент на ЈЗУ Универзитетска клиника за неврохирургија од 2011 до 2016 год. со различни манифестации на мозочни крвавења. Пациентите беа поделени во 2 групи: со и без нагласени ризик-фактори. Во групата со нагласени ризик-фактори се утврди дека 15 испитаници консумирале алкохол. Беа испитувани следниве варијабли: пол, возраст, волумен на крвавењето, компресија, исход на лекувањето и функционална мобилност. Резултати: Резултатите укажуваат дека алкохолизмот значително влијае на појавата на мозочните крвавења, особено кај болните што консумираат повеќе од $200 \mathrm{ml}$ алкохол дневно. Најверојатна причина е оштетувањето на црниот дроб и нарушувањето на хемостазата. Заклучок: Алкохолизмот како социомедицински фактор има сигнификантна улога во појавата на мозочните крвавења.

\section{PUBLIC HEALTH}

\section{EVALUATION OF THE INFLUENCE OF ALCOHOLISM AS A SOCIAL-MEDICAL FACTOR ON THE OCCURRENCE OF BRAIN HEMORRHAGES}

Ivan Pangovski ${ }^{1}$

Institute of Social Medicine, Faculty of Medicine, Ss. Cyril and Methodius University in Skopje, Republic of North Macedonia

Citation: Pangovski I. Evaluation of the influence of alcoholism as a social-medical factor on the occurrence of brain hemorrhages. Arch Pub Health 2019; 11 (1): 31-36 (Macedonian)

Key words: alcoholism, brain hemorrhages, hypertension, atherosclerosis, risk factors, public health aspect

*Correspondence:Ivan Pangovski, Institute of social medicine, Faculty of Medicine, Ss. Cyril and Methodius University in Skopie, Republic of North Macedonia. E-mail:ivan.pangovski@gmail.com Received: 26-Nov-2018; Revised: 23-Jan-20199 Accepted: 28-Feb-2019; Published: 15-Mar-2019

Copyright: ${ }^{\odot}$ 2019. Ivan Pangovski. This is an open-access article distributed under the terms of the Creative Commons Attribution License which permits unrestricted use, distribution, and reproduction in any medium, provided the original author(s) and source are credited.

Competing Interests: The author have declared that no competing interests

\section{Abstract}

Purpose of the paper: To determine the effect of alcohol consumption on the emergence and treatment of hypertensive brain hemorrhages and the harmful effects on morbidity and mortality of patients. Material and methods: A retrospective study of 61 patients was performed at the University Clinic of Neurosurgery from 2011 to 2016 with various manifestations of brain bleeding. Patients were divided into 2 groups: with and without emphasized risk factors. In the group with emphasized risk factors 15 examinees consumed alcohol. The following variables were examined: sex, age, bleeding volume, compression, the outcome of treatment and functional mobility. Results: The results indicate that alcoholism significantly affects the onset of brain bleeding, especially in patients who consume more than $200 \mathrm{ml}$ of alcohol per day. The most likely cause is liver damage and hemostasis disorder. Conclusion: Alcoholism as a socio-medical factor has a significant role in the occurrence of brain hemorrhages. 


\section{Вовед}

Злоупотреба на алкохол е консумирање алкохол во големи количини и тоа на таков начин што може да ја оштети или да ја загрози благосостојбата на индивидуата или лицата со кои доаѓа во контакт.Злоупотребата на алкохолот има силно влијание врз јавното здравје. Таа генерира трошоци за здравствена заштита, за здравственото осигурување, за примената на прописите, за одржување на јавниот ред и мир, за заштита на работната средина, како и други фактори што има негативно влијание врз функционирањето на семејствата, а со тоа и врз социоекономскиот развој на општеството во целост ${ }^{1,2}$.

Хеморагичниот мозочен удар претставува „завршен чин” на скриените промени на мозочните крвни садови. Патолошките промени започнуваат од самото раѓање и зависно од васкуларните промени и факторите на ризик се манифестират низ целиот живот. Спонтаните интрацеребрални хематоми се тесно поврзани со заболувањето на крвните садови на витално најважниот орган - мозокот и до денес го задржуваат епитетот на „масовен убиец” 3,4.

Мозочните хеморагии настануваат при руптура или дисекција на мозочните крвни садови. Излевањето на крвта прави деструкција, компресија и дислокација на околното ткиво и појава на мозочен едем. Токму затоа мозочните крвавења се доминантна причина за многу изгубени животи и инвалидитет во модерното општество 5 .

Долгогодишното уживање на алкохол делува на сите органи, а пред сѐ на црниот дроб. Доаѓа до смалување на коагулационите фактори, нарушување на хемостазата и продолжување на времето на крвавење, хипертензија, атероскелроза. На тој начин алкохолот директно влијае врз појавата на мозочните крвавења ${ }^{6}$.

\section{Епидемиолошки податоци}

Злоупотребата на алкохол е одговорна за околу 9\% од вкупниот морбидитет во европскиот регион, зголемувајќи го ризикот одпојава на хепатална цироза, одредени видови карцином, хипертензија, инсулт и конгенитални малформации. Се проценува дека годишно од зависност од алкохол заболуваат 23 милиони луѓ во Европа (5\% мажи и $1 \%$ жени). Во Македонија се проценува дека над 60.000 луѓе се алкохоличари, а 300.000 имаат проблеми со алкохолот и покажуваат знаци на алкохолна болест ${ }^{7,2}$.

Генерално, спонтаните мозочните крвавења изнесуват само 10\% од сите мозочниудари. Во Р. Македонија се регистрирани 100 случаи на 100.000 жители. Интрацеребралните крвавења се застапени со 20\% од ова заболување. Во нашата држава годишно се лекуваат околу 200 пациенти, а останатите им припаѓаат на исхемичните мозочни удари ${ }^{2,8}$.

Кај мозочните крвавења морталитетот се движи од 40 до 50\%. Морбидитетот е силно изразен; само 15\% од пациентите по завршеното лекување остануваат работоспособни. Околу $30 \%$ од пациентите дневните активности ги извршуваат со помагала, а 35\% се „приковани“ за леглои зависни од туѓa нега ${ }^{8}$.

Бројни студии укажуваат дека социомедицинските ризик-фактори се воедно и најдоверливите прогностички фактори за намалување на фреквенцијата на мозочните крвавења. Тука спаѓаат: неадекватна исхрана, пушење, консумирање алкохол, намалување на физичката активност, стрес, шеќерна болест и хиперлипидемија. Делувајќи на факторите на ризик во развиените земји инциденцијата на мозочните крвавења е смалена за преку 20\%, морталитетот е намален за 15\%, а морбидитетот за $10 \%$ 8,9,4,

Цел на трудот е да се утврди влијанието на консумирањето алкохол во појавата и лекувањето на хипертензивните мозочни крвавења и штетните последици врз морбидитетот и морталитетот на пациентите.

\section{Материјал и методи}

Беше изведена ретроспективна студија кај 61 пациент на Ј3У Универзитетска 
клиника за неврохирургија од 2011 до 2016 г. со различни манифестации на мозочни крвавења. Пациентите беа поделени во 2 групи: со и без нагласени ризик-фактори. Во групата со нагласени ризик-фактори беше утврдено дека 15 испитаници конзумирале алкохол. Беа испитани следните варијабли: пол, возраст, волумен на крвавењето, компресија, исход на лекувањето и функционална мобилност. Сите овие податоци беа внесени во попис на специјални листи кои Клиниката ги поседува учествувајќи во интернационален проект (STICH I и II - Newcastle, Great Britain) во која учествуваа 66 земји од сите континенти ${ }^{4,8}$.

Од факторите на ризик кај алкохолот постојат 3 параметри: умерена консумација до $90 \mathrm{ml}$ дневно, прекумерна до $200 \mathrm{ml}$ дневно и екстремна над $200 \mathrm{ml}$ дневно ${ }^{4}$.

Со статистичка обработка беше направена корелација помеѓу ризик-факторите (алкохолизмот) и атрибутите на крвавење со Chi-square.

\section{Резултати}

Според пол, мажите (од 2015-2016) беа повеќе застапени во однос на жените (88,1\% мажи, а 11,9\% жени во 2016г. и 88,7\% мажи, а 11,3\% жени во 2015 г.). Испитаниците беа на возраст од 45 до 71 година, со просечна возраст од 58 години.

Волуменот на интрецеребралното крвавење имаше просечна вредност од 44 ccm3. Кај 5 испитаници волуменот на крвавење беше над 40 ccm3, додека кај најголем број испитаници, односно 60\% волуменот на крвавење се движеше од 30 до $40 \mathrm{ccm} 3$, а само кај 1 испитаник изнесуваше помалку од 30 ccm3 (Табела бр.1).

Кај 11 од 15 испитаници беше присутна компресија на хематомот, односно 73,3\%, а од нив сите беа оперирани. Локална компресија беше присутна кај 9 испитаници, односно 60\%, а поместување на средишни структури имаше кај останатите 6 испитаници (40\%).

Летален исход беше верифициран кај 8 пациенти (53,3\%). Во однос на морбдитетот 1 пациент беше работоспособен, 3 пациенти се движеа со помагала и 3 пациенти беа зависни од туѓa нега.

Табела 6p 1. Дистрибуција според волумен на крвавење

\begin{tabular}{|l|c|}
\hline Волумен на крвавењето & $\mathrm{N}(\%)$ \\
\hline до 30 ссm3 & $1(6,67 \%)$ \\
\hline $30-40$ cсm3 & $9(60 \%)$ \\
\hline над $40 \mathrm{ccm} 3$ & $5(33,34 \%)$ \\
\hline
\end{tabular}

Табела 6p 2. Дистрибуција според исход на лекувањето

\begin{tabular}{|l|c|}
\hline Исход од лекувањето & $\mathrm{N}(\%)$ \\
\hline Летален исход & $8(53,3 \%)$ \\
\hline Пациенти што се движеа со помагала & $3(20 \%)$ \\
\hline Зависни од туѓа нега & $3(20 \%)$ \\
\hline Работоспособни & $1(6,7 \%)$ \\
\hline
\end{tabular}

Во однос на функционалната мобилност, евидентни беа тешки невролошки секвели кај пациентите кои консумираа големи количини алкохол.

Табела 6p 3. Дистрибуција според функционална мобилност

\begin{tabular}{|l|c|}
\hline Функционална мобилност & $\mathrm{N}(\%)$ \\
\hline можност за самостојно функционирање & $1(13,32 \%)$ \\
\hline Можност за дневни активности со помош или помагала & $7(46,67 \% \%)$ \\
\hline Приковани за кревет, зависни од туѓа нега & $6(40 \%)$ \\
\hline
\end{tabular}


Од анализираните 15 пациенти, кај само 3 беше присутно умерено уживање на алкохол, кај 6 прекумерно, а кај останатите 6 екстремно консумирање алкохол.

Резултатите укажуваат дека алкохолизмот значително влијае на појавата на мозочните крвавења, особено кај бо- лните што консумираат повеќе од 200 $\mathrm{ml}$ алкохол дневно. Најверојатна причина е оштетувањето на црниот дроб и нарушување на хемостазата. Во однос на морбидитетот и морталитетот, статистички алкохолизмот претставува предиктивен фактор со $5<0,01(4,8,10)$.

Табела 6p 4. Дистрибуција според консумација на алкохол

\begin{tabular}{|c|c|c|}
\hline Пиење алкохол & $\mathrm{N}(\%)$ & \multirow{4}{*}{$\begin{array}{l}\text { Chi-square: } 1,84 \\
\mathrm{df}=1, \mathrm{p}=0,175 \mathrm{~ns}\end{array}$} \\
\hline Умерено до $90 \mathrm{ml}$ дневно & $3(20 \%)$ & \\
\hline Прекумерно до $200 \mathrm{ml}$ дневно & $6(40 \%)$ & \\
\hline Екстремно над $200 \mathrm{ml}$ дневно & $6(40 \%)$ & \\
\hline
\end{tabular}

\section{Дискусија}

Резултатите од компаративните студии укажуваат дека алкохолизмот е со доминантна полова застапеност кај мажите. Консумирањето алкохол во прекумерни дози од над 200ml дневно претставува сериозна закана по здравјето на пациентите. Се проценува дека преку 30\% алкохолот учествува во нарушувањата на мозочните функции и појава на мозочни крвавења. Иако се работи за мала серија на анализирани пациенти (15), резултатите го потврдуваат големото штетно влијание на алкохолизмот врз функционалниот исход и смртноста ${ }^{4,8}$.

Податоците достапни од литературата покажуваат слични перформанси во однос на предиктивните фактори потврдени и во нашата анализа. Возраста, волуменот на крвавењето и компресијата имаат силна негативна прогноза во исходот на лекувањето. Треба да се потенцира дека само еден ризик-фактор не претставува услов за појава на мозочно крвавење. Атеросклерозата, хипертензијата, покачените вредности на шеќер, липиди, физичката неактивност и стресот ја потенцираат можноста за руптура на мозочните крвни садоВи ${ }^{4,8,11}$.

Покачениот крвен притисок е најзначаен хемодинамски фактор кај мозочните крвавења. Според податоците од клиниката MASO, 70\% од луѓето имале покачен крвен притисок над $170 \mathrm{~mm} /$ $\mathrm{Hg}$ кај кои бил евидентиран интра- церебрален хематом. Кај пациентите хоспитализирани на неврохируршката клиника, 76\% имале неконтролирана хипертензија. Кај пациентите кои имаат зголемен крвен притисок, процесот на атеросклероза е значително побрз во споредба со испитаниците кај кои не е присутна хипертензија. Сето ова драматично го зголемува морбидитетот и морталитетот кај болните ${ }^{4,8,9}$.

Генерално, евакуацијата на крвавењето по хируршки пат е најзначајна и животоспасувачка. Најбитен предуслов за добра оперативна интервенција е да се направи брза евакуација на крвавењето, декомпресија, без функционално оштетување на елоквентните структури. Суштински најдобри резултати се постигнуваат при отстранување на лобарните хематоми, додека во оние локализирани во базалните ганглии не постои разлика помеѓу хируршката и конзервативната терапија ${ }^{4,7,8}$.

Функционалниот исход и мобилноста, колку и да се генерално незадоволителни, укажуваат дека е неопходна превенција за елиминирање или намалување на постојните ризик-фактори, а особено на алкохолизмот. Тоа е тесно поврзано со многу социоекономски предуслови и потреба од дополнителни финансиски средства за лекување во третата фаза на рехабилитација ${ }^{4,8,12}$.

Најновите истражувања спроведени од американските научници од Универзитетот Северна Каролина укажуваат на штетните последици од прекумерна 
консумација на алкохол врзклетките на мозокот. Досега се сметало дека невродегенерацијата не се јавува за време на самото пијанство, туку за време на повлекувањето на алкохолот од телото. Се истакнува дека трошоците за лекување во САД изнесуваат преку 4 милијарди долари на годишно ниво само за хеморагичните мозочни инсулти ${ }^{12,4,2}$.

Бројот на специјалисти кои се ангажирани во лекување на ова заболување е значително мал насекаде во светот, а особено во нашата држава. Токму затоа императивно неопходно е да се зголеми бројот на лекари, пред сѐ на специјалисти од јавно здравство кои ќе делуваат првенствено на превенцијата на цереброваскуларните заболувања ${ }^{1,4}$.

Од јавноздравствена перспектива употребата на алкохол претставува уникатна дилема која се нарекува „превенциски парадокс“. Здравствените и економските последици што произлегуваат од употребата на алкохолот се резултат на хазардерско пиење до постигнување на формална дијагноза на алкохолна зависност. Здравиот начин на живот (правилна исхрана, психичка и телесна релаксација, избегнување никотин и алкохолни производи) е најсигурен пат до постигнување на подобри резултати ${ }^{13,12,6}$.

\section{Заклучок}

Алкохолот, освен на мнестичките функции преку глобална атрофија, влијае и на крвните садови на мозокот предизвикувајќи хеморагични мозочни инсулти. Алкохолизмот како социомедицински фактор има сигнификантна улога во појавата на мозочните крвавења. Потребно е да се засилат активностите во однос на превенција на употребата на алкохол преку мноштво социомедицински акциони планови и стратегии. Затоа, и покрај тоа што производството, продажбата и употребата на алкохолните пијалоци се регулирани со силни закони и даноци, сепак треба да се потенцираат штетностите кои ги предизвикуваат врз здравјето на човекот.

За достигнување на оптимални резултати на ова „масовно заболување“ не постои стратегија на избор. Според сознанијата и актуелните анализи во современата литература, максимално спроведената превентива, оптималната хируршка декомпресија и рационално поставена конзервативна и физикална терапија се фундаментални предуслови за подобрување на квалитетот и квантитетот на преживување кај пациентите.

\section{Референци}

1. Casolla B, Dequatre - Ponchelle N, Rossi C, Henon H, Leys D. Heavy alcohol intake and intracerebral hemorrhage. Neurology 2012; 79(11):1109-1115

2. Институт за јавно здравје. Информација за состојбата со болестите на зависност во Република Македонија, 2015-2016, Скопје.

3. Weisberg LA. Alcoholic intracerebral hemorrhage. Stroke 1988; 19(12): 1565-1569.

4. Панговски Иван. Фреквенција и значење на социо-медицинските ризик фактори во превенција на спонтаните хипертензивни мозочни крварења. Магистерски труд, 2016. Медицински факултет - Скопје.

5. Gebel JM, Jauch EC, Brott TG, Jane K, Sauerbeck L, Salisbury S, et al. Relative edema volume is a predictor of outcome in patients with hyperacute intracerebral hemorrhage. Stroke 2002; 33 (11): 2636-2641

6. Ching - Jen C, Brown W M, MoomawC J, Langefeld C, Osborne J, Worrall B B, et al. Alcohol use and risk of intracerebral hemorrhage. Neurology 2017; 88(21):2043-2051.

7. Juvela S. Alcohol abuse and hemorrhagic stroke. In book: Alcohol and heart disease, Publisher: Taylor \& Francis, London, Editors: Watson RR, Myers AK, pp. 58-71. University of Helsinki, Helsinki, Finland

8. Панговски И, Шумковски Р, Гавриловска А, Рендевски В, Панговски Ив. Важноста, Актуелнос- 
та и значењето на лекувањето на спонтаните интрацербрални хематоми. Зборник на трудови. Неврохируршки симпозиум за интрацеребрални крварења, Скопје 2010

9. Indira $\mathrm{Y}$, Muralidhar $\mathrm{MV}, \mathrm{Mu}-$ nisekhar K. Role of smoking and alcoholism in cerebrovascular accidents. International Journal of Physiotherapy and research 2014; 2(3):530-536

10. Gever J, Senior Editor, Med Page Today, 25 June, 2009. Heavy daily drinking boosts chances of lethal brain hemorrhage. Available at https://www.medpagetoday.org/ criticalcare/strokes/14868

11. Herzig R, Urbanek K., Vlachova I.,
Schneiderka P, Mares J. The Role of Chronic alcohol intake in patients with spontaneous intracranial hemorrhage: A Carbohydrate - Deficient Transferin Study. Cerebrovasc Dis 2003; 15:22-28.

12. Klatsky A L, Armstrong M A, Friedman G D, Sidney S. Alcohol drinking and risk of hemorrhagic stroke. Neuroepidemiology 2002; 21:115122.

13. Costa P, Grassi M, Iacoviello L, Zedde M. Alcohol intake and the risk of intracerebral hemorrhage in the elderly, The MUCH - Italy. Neurology 2018; 91(3):e227-e235. 